\title{
PENGARUH STRUKTUR MODAL, KEBIJAKAN DIVIDEN DAN LIKUIDITAS TERHADAP PROFITABILITAS PERUSAHAAN PERBANKAN DI BURSA EFEK INDONESIA
}

\author{
Willy Tantono ${ }^{1}$ \\ Made Reina Candradewi ${ }^{2}$ \\ ${ }^{1,2}$ Fakultas Ekonomi dan Bisnis Universitas Udayana (Unud), Bali, Indonesia \\ email: willytantono22@gmail.com
}

\begin{abstract}
ABSTRAK
Penelitian ini dilakukan untuk menguji pengaruh struktur modal, kebijakan dividen dan likuiditas terhadap profitabilitas bank yang terdaftar di Bursa Efek Indonesia periode 20152017. Penelitian ini adalah penelitian asosiatif. Populasi dari penelitian ini adalah 39 perusahaan dan diamati selama tahun 2015 hingga 2017. Teknik sampling yang digunakan dalam penelitian ini adalah sampel jenuh. Berdasarkan teknik ini, 39 perusahaan diperoleh sebagai sampel. Penelitian ini menggunakan data sekunder dari BEI. Metode pengumpulan data yang digunakan dalam penelitian ini adalah metode observasi non partisipan. Peneliti menggunakan regresi linear berganda sebagai teknik analisis. SPSS 20 digunakan untuk membantu menganalisis. Hasil analisis dapat disimpulkan bahwa struktur modal memiliki pengaruh negatif signifikan terhadap profitabilitas, kebijakan dividen berpengaruh positif signifikan terhadap profitabilitas dan likuiditas berpengaruh positif signifikan terhadap profitabilitas.
\end{abstract}

Kata kunci: profitabilitas, struktur modal, kebijakan dividen, likuiditas

\begin{abstract}
This study was conducted to examinate the effect of capital structure, dividend policy and liquidity on profitability of bank that listed on Indonesia Stock Exchange period of 2015 to 2017. This study was associative research. The population of this study were 39 companies and observed during 2015 to 2017. The sampling technique used in this study was saturated samples. Based on these techniques, 39 companies obtained as samples. This study used the secondary data from IDX. The data collection methods used in this study was non participant observation method. The researcher used multiple linear regression as the analytical technique. SPSS 20 was used to help analyze. The result of analysis can be conclude Capital Structure had significant negative effect on profitability, Dividend policy had significant positive effect on profitability and Liquidity had positive significant effect on profitability.

Keywords: profitability, capital structure, dividend policy, liquidity
\end{abstract}




\section{PENDAHULUAN}

Profitabilitas merupakan salah satu tolok ukur keberhasilan suatu perusahaan. Profitabilitas adalah kemampuan perusahaan untuk menghasilkan keuntungan (profit) dan untuk mengukur tingkat efisiensi operasional dan penggunaan harta yang dimilikinya (Chen dan Dhiensiri, 2009). Profitabilitas sangat penting bagi perusahaan, profit yang perusahaan sendiri dapatkan sangat berguna untuk kegiatan pendanaan perusahaan atau dijadikan dividen untuk para pemegang saham yang telah berkontribusi membantu pendanaan perusahaan. Selain itu profitabilitas perusahaan juga merupakan suatu daya tarik bagi investor sehingga apabila dirasa sebuah perusahaan memiliki profitabilitas yang tinggi, investor cenderung berinvestasi pada perusahaan tersebut. Setiap perusahaan akan berharap profitabilitas perusahaannya akan terus meningkat tetapi pada kenyataannya banyak perusahaan yang profitabilitasnya cenderung tidak stabil. Hal ini sangat penting untuk diperhatikan dan diteliti lebih lanjut.

Profitabilitas juga sangat penting bagi perusahaan perbankan. Keuntungan tersebut digunakan untuk menambah modal bank disamping juga untuk dibagikan kepada para pemegang saham (Sudirman, 2013:151). Profitabilitas juga merupakan indikator dalam menentukan tingkat kesehatan bank yang diregulasi oleh Bank Indonesia yaitu aspek rentabilitas (Sudirman, 2013:108). Indikator ini pula yang menjadi pertimbangan investor untuk menginvestasi dana yang dimilikinya. Investor akan cenderung menginvestasikan dananya kepada perusahaan perbankan yang sehat dan mampu mensejahterakan para pemegang saham. 
Profitabilitas perusahaan perbankan memiliki permasalahan yang sama dengan perusahaan lainnya yaitu profitabilitas yang tidak stabil atau tidak selalu meningkat. Berikut merupakan data mengenai rata-rata profitabilitas perusahaan perbankan yang terdaftar di Bursa Efek Indonesia selama periode 2015-2017. Profitabilitas diproksikan dengan rasio Return On Assert.

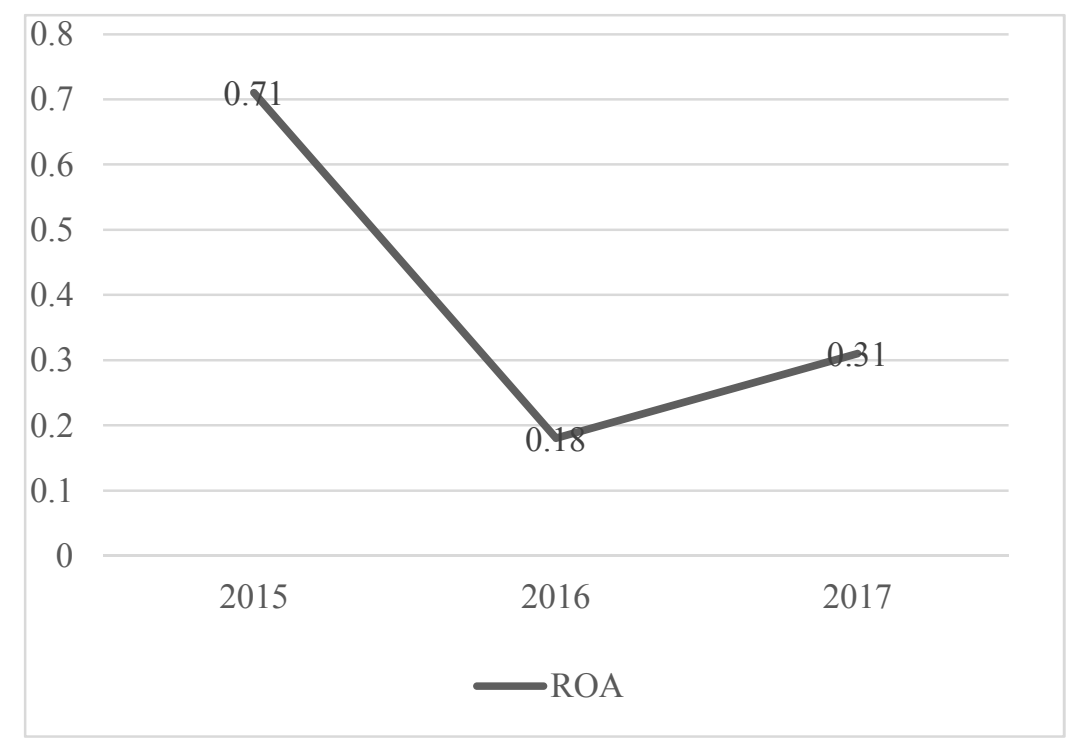

Gambar 1.Grafik Rata-rata Rasio Return On Asset Perusahaan Perbankan di Bursa Efek Indonesia Periode 2015-2017

Sumber: data diolah, 2018

Gambar 1. menunjukan terjadi penurunan dan kenaikan rasio return on asset perusahaan perbankan di Bursa Efek Indonesia selama periode 2015 hingga 2017. Profitabilitas perusahaan perbankan selama periode pengamatan cenderung tidak stabil. Hal ini merupakan masalah bagi perusahaan perbankan di Bursa Efek Indonesia. Perusahaan perbankan perlu mengambil kebijakan yang baik agar kestabilan kenaikan profitabilitas dapat terus terjadi.

Profitabilitas menjadi sangat penting bagi perusahaan perbankan, sehingga manajer akan mengambil keputusan dan kebijakan yang akan mempengaruhi 
profitabilitas perusahaan perbankan. Manajer akan berusaha agar profitabilitas perusahaan menjadi meningkat dengan sehingga pemegang saham akan menilai perusahaan tersebut menjadi perusahaan yang layak untuk diinvestasikan. Manajer perusahaan akan mengambil kebijakan mengenai struktur modal yang merupakan kebijakan pendanaan, kebijakan dividen dan likuiditas yang merupakan kebijakan terkait investasi jangka pendek.

Struktur modal merupakan faktor penting yang dapat mempengaruhi profitabilitas. Struktur modal (capital structure) merupakan kombinasi hutang dan ekuitas dalam struktur keuangan jangka panjang perusahaan. Keputusan ini didasarkan oleh pertimbangan pengoptimuman pendanaan dan kombinasi penggunaan dana dari luar perusahaan (utang). Brigham dan Houston (2011) mengatakan struktur modal yang optimal dapat mengalami perubahan dari waktu ke waktu, di mana perubahan dalam struktur modal akan mempengaruhi tingkat risiko dan biaya dari masing-masing jenis modal, dan hal ini dapat mengubah ratarata tertimbang biaya modalnya. Dengan menekan biaya modalnya maka perusahaan dapat meningkatkan jumlah pendapatan atau profit perusahaan.

Penelitian terdahulu oleh Ronoh and Ntoiti (2015), Chechet dan Olayiwola (2014), Rifai (2014), dan Afriyanti (2011) terdapat hubungan negatif signifikan antara rasio utang terhadap profitabilitas, hasil temuan tersebut mengindikasikan bahwa semakin kecil struktur modal yang digunakan perusahaan menyebabkan semakin meningkatnya profitabilitas perusahaan yang sejalan dengan pecking order theory struktur modal. Dalam penelitian lain oleh Penelitian lain yang dilakukan oleh Binangkit dan Raharjo (2014), Javaid et al. (2012), Akhtar and Sadaqat (2011), 
serta Marusya dan Magantar (2016) menyatakan hal yang berbeda, bahwa struktur modal berpengaruh signifikan positif terhadap profitabilitas, hal ini mengindikasikan apabila semakin besar presentase struktur modal maka akan semakin pula tingginya profitabilitas perusahaan. Hasil temuan ini selaras dengan trade off theory struktur modal. Hasil penelitian lainnya yang dilakukan oleh Velnampy dan Niresh (2012) dan Shaputri dkk. (2016) menyatakan bahwa struktur modal berpengaruh positif terhadap profitabilitas namun tidak signifikan.

Dividen adalah laba bersih yang dibagikan kepada pemegang saham (Rismawati dan Dana, 2014). Dana ini diberikan perusahaan kepada investor karena telah memiliki saham perusahaan. Pengambilan keputusan untuk membagi dividen memerlukan banyak hal yang harus dipertimbangkan seperti kemampuan perusahaan dalam pembentukan dana intern akan semakin besar apabila keuntungan atau laba yang diperoleh ditahan sebagai laba ditahan. Perusahaan perbankan yang membagikan dividennya memiliki citra yang lebih dimata nasabah sehingga perusahaan yang membagikan dividennya dianggap perusahaan yang memiliki kesehatan bank yang baik, sehingga kepercayaan nasabah akan meningkat dan profitabilitas perusahaan perbankan akan meningkat juga.

Penelitian oleh Thafani dan Abdullah (2014), Ajanthan (2013) dan Abiola (2014) menjelaskan bahwa kebijakan dividen berpengaruh positif signifikan terhadap profitabilitas. Hal ini didukung oleh Fauzi dan Suhadak (2015) serta oleh M'rabet dan Boujjat (2016) berkesimpulan bahwa kebijakan dividen berpengaruh positif signifikan terhadap profitabilitas. Sedangkan dalam penelitian Farsio et al. 
(2004) dikatakan bahwa tidak ada pengaruh antara kebijakan dividen terhadap profitabilitas.

Likuiditas adalah kemampuan perusahaan menyediakan dana untuk melunasi kewajibannya setiap saat (Wiagustini, 2013:85) . Bagi perusahaan perbankan aspek likuiditas ini dipandang penting karena operasional perusahan tergantung pada likuiditas, likuiditas bagi perbankan berkaitan dengan penggunaan dana dari nasabah untuk memperoleh profit melalui penyaluran kredit. Semakin tinggi tingkat likuiditas perbankan maka akan semakin banyak idle money atau uang menganggur yang seharusnya dapat dimanfaatkan perbankan untuk meningkatkan profit perusahaan dengan menyalurkannya sebagai kredit kepada nasabah. Apabila tingkat likuiditas perusahaan perbankan rendah maka akan muncul kekhawatiran nasabah akan kemampuan bank mengembalikan tabungan milik nasabah yang akan menimbulkan money rush yang akan mempersulit keadaan perusahaan oleh karena itu likuiditas berhubungan pula dengan kepercayaan para nasabah (Veithzal dkk., 2007). Pada penelitian ini likuiditas diukur dengan menggunakan Loan to Deposit ratio (LDR). LDR adalah rasio yang paling umum dipergunakan di dalam mengukur likuiditas perbankan (Sudirman, 2013:185). LDR merupakan perbandingan antara jumlah kredit yang disalurkan dengan jumlah dana yang digunakan, modal sendiri dan juga dana masyarakat yang dihimpun (Kasmir, 2011:225). Tingkat LDR dapat mempengaruhi profitabilitas pada suatu bank.

Penelitian terdahulu yang dilakukan oleh Miadalyni (2013), Agustiningrum (2013), Fahrul and Rusliati (2016) serta Fahrizal (2014) mendapatkan hasil bahwa likuiditas berpengaruh positif dan signifikan terhadap profitabilitas. Temuan 
tersebut bertentangan dengan penelitian Habbe et al. (2012), Audhya (2014) dan Paleni et al. (2017) dimana diperoleh hasil yaitu likuiditas berpengaruh negatif signifikan terhadap profitabilitas. Penelitian oleh Zaineldeen (2018) yang dilakukan di Palestina juga memperoleh hasil bahwa likuiditas berpengaruh negatif signifikan terhadap profitabilitas. Sukmawati dan Purbawangsa (2016), Damayanti (2010), Warsa dan Mustanda (2016) dan Purwoko (2013) yang menyatakan bahwa likuiditas berpengaruh positif namun tidak signifikan terhadap profitabilitas.

Pecking Order Theory adalah teori mengenai keputusan struktur modal perusahaan berdasarkan urutan preferensi dalam penggunaan dana. Berdasarkan Pecking Order Theory urutan penggunaan dana tersebut adalah sebagai berikut. Perusahaan memilih pendanaan internal, perusahaan menghitung target rasio pembayaran didasarkan pada perkiraan kesempatan investasi, perusahaan berusaha menghindari perubahan dividen yang tiba-tiba, jika perusahaan memiliki aliran kas yang cukup besar, perusahaan akan membayar hutang atau membeli surat berharga. Sedangkan bila aliran kas tersebut lebih kecil, perusahaan akan menggunakan kas yang dipunyai atau menjual surat berharga, jika pendanaan eksternal diperlukan, perusahan akan mengeluarkan surat berharga yang aman terlebih dahulu, mulai dengan hutang kemudian yang terakhir saham.

Pendanaan internal perusahaan merupakan pendanaan yang paling sedikit memerlukan biaya dibandingkan dengan pendanaan eksternal. Penggunaan hutang (pendanaan eksternal) yang tinggi menyebabkan biaya bunga meningkat sehingga profitabilitas perusahaan menurun. Selain itu keuntungan pendanaan internal adalah perusahaan tidak perlu mengeluarkan biaya penerbitan surat utang. Sesuai 
dengan Pecking Order Theory pendanaan utama bagi perusahaan adalah pendanaan internal untuk pembiayaan investasi, kemudian apabila pendanaan internal tidak mencukupi maka dilakukan pendanaan eksternal yang dimulai dari pendanaan dari penerbitan surat utang kemudian pendanaan dari penerbitan saham baru. Selain itu pendanaan internal juga memiliki kelebihan dari pada pendanaan eksternal yaitu pendanaan internal lebih tidak berisiko dibandingkan dengan pendanaan eksternal perusahaan sehingga keuntungan yang disyaratkan oleh investor tidak akan meningkat.

Penggunaan pendanaan eksternal khususnya hutang akan meningkatkan risiko perusahaan mengalami kesulitan keuangan (financial distress) yang nantinya akan meningkatkan kekuatiran investor dan akan berdampak pada meningkatnya biaya agensi. Sehingga pendanaan internal akan sangat membantu mengurangi biaya sehingga profitabilitas perusahaan akan terjaga atau tidak berkurang (Radjamin dan Sudana, 2014).

Struktur modal adalah rasio perbandingan antara jumlah utang dengan modal sendiri. Struktur modal dapat diukur dengan debt to equity ratio (DER). DER merupakan rasio yang digunakan untuk mengetahui perbandingan antara total utang dengan modal sendiri (Kasmir, 2011). Penggunaan hutang yang tinggi menyebabkan biaya bunga meningkat sehingga profitabilitas perusahaan menurun.

Penelitian Rifai (2014) mendapatkan hasil bahwa struktur modal memiliki pengaruh yang negatif signifikan terhadap profitabilitas pada perusahaan manufaktur di BEI, selain itu penelitian yang dilakukan Afriyanti (2011) 
memperoleh hasil bahwa struktur modal berpengaruh negatif signifikan terhadap profitabilitas, serta penelitian yang dilakukan oleh Chechet dan Olayiwola (2014) mendapatkan hasil yang sama juga bahwa struktur modal berpengaruh negatif signifikan terhadap profitabilitas, hal ini sesuai dengan pecking order theory yang menjelaskan bahwa pendanaan dari hutang (pendanaan eksternal memiliki risiko menurunkan keuntungan). Berdasarkan penjelasan di atas dirumuskan hipotesis sebagai berikut:

$\mathrm{H}_{1}$ : Struktur modal berpengaruh negatif signifikan terhadap profitabilitas.

Menurut Sartono (2012:281), kebijakan dividen adalah kebijakan mengenai apakah profit yang telah diperoleh perusahaan akan dibagikan kepada para pemegang saham dalam bentuk dividen atau akan disimpan dalam bentuk laba ditahan untuk pembiayaan investasi di masa yang akan datang. Kebijakan dividen yang akan diabil oleh perusahaan akan menjadi sebuah informasi pasar mengenai prospek perusahaan kedepannya. Informasi kepada pasar atau investor mengenai keadaan dan prospek perusahaan dapat dilihat dari kebijakan dividen. Kenaikan pembayaran dividen memberikan signal bagi para nasabah. Hal ini akan meningkatkan citra perusahaan itu sendiri. Nasabah juga memperhatikan sinyal tersebut sehingga perusahaan yang membagikan dividen tersebut, sehingga perusahaan yang membagikan dividennya memiliki citra yang lebih baik dari perusahaan yang tidak membagikan dividennya. Perusahaan yang citranya lebih baik akan meningkatkan kepercayaan masyarakat dan akan meningkatkan profitabilitas perusahaanya. Berdasarkan hal tersebut dapat disimpulkan bahwa kebijakan dividen berpengaruh positif terhadap profitabilitas. 
Penelitian yang dilakukan oleh Ajanthan (2013) memberikan hasil bahwa kebijakan dividen berpengaruh positif signifikan terhadap profitabilitas perusahaan hotel dan restoran di Sri Lanka, selain itu penelitian yang dilakukan Fauzi dan Suhadak (2015) juga memperoleh hasil bahwa kebijakan dividen berpengaruh positif signifikan terhadap profitabilitas perusahaan dan penelitian M'rabet dan Boujjat (2016) memberikan hasil bahwa kebijakan dividen berpengaruh positif signifikan terhadap profitabilitas perusahaan. Berdasarkan penjelasan di atas dirumuskan hipotesis sebagai berikut:

$\mathrm{H}_{2}$ : Kebijakan dividen berpengaruh positif signifikan terhadap profitabilitas.

Likuiditas perusahaan menunjukkan kemampuan perusahaan untuk memenuhi kewajiban finansial yang berjangka pendek tepat pada waktunya, yang ditunjukkan oleh besar kecilnya aktiva lancar. Rasio likuiditas dalam penelitian ini diukur dengan menggunakan loan to deposit ratio. Likuiditas ini mempunyai hubungan yang erat dengan profitabiltas, karena likuiditas memperlihatkan tingkat ketersediaan modal kerja yang dibutuhkan dalam aktivitas operasional (Saleem dan Rehman, 2011).

Keuntungan yang diterima bank utamanya berasal dari pendapatan bunga pinjaman debitur. Semakin banyak penyaluran kredit yang diberikan perbankan maka akan semakin meningkat pula profitabilitas perusahaan perbankan. Apabila kredit yang disalurkan lebih besar dibandingkan dana nasabah maka akan terjadi keadaan ilikuid, sedangkan apabila jumlah kredit yang disalurkan lebih kecil dari pada dana nasabah maka akan berakibat adanya dana yang mengganggur (iddle 
cash), dan hal ini akan berpengaruh kepada jalannya kegiatan operasional perbankan. Bank dalam kondisi illikuid akan mengalami kesulitan untuk mendapatkan kepercayaan masyarakat sehingga akan menyulitkan kegiatan operasional sehingga berdampak terhadap tinggi rendahnya profitabilitas. Menurut Sartono (2012) menyatakan bahwa likuiditas juga berpengaruh positif terhadap profitabilitas perusahaan.

Perubahan yang terjadi pada jumlah kredit yang disalurkan atau dana nasabah akan berpengaruh terhadap keuntungan bank. Berdasarkan pendapat para ahli disimpulkan bahwa perubahan likuiditas akan mempengaruhi profitabilitas, karena semakin baik kemampuan perusahaan untuk membayar kewajiban jangka pendeknya menunjukkan bahwa perusahaan tersebut mampu memperoleh laba yang tinggi untuk membayarnya kewajibannya

Hasil penelitian terdahulu oleh Miadalyni (2013) dan Agustiningrum (2013) mendapatkan kesimpulan yaitu likuiditas mempunyai pengaruh positif signifikan terhadap profitabilitas. Fahrizal (2014) memperoleh hasil penelitian yang sama yaitu likuiditas berpengaruh positif dan signifikan terhadap profitabilitas. Berdasarkan pemikiran di atas, hipotesis yang dapat diajukan dalam penelitian ini adalah:

$\mathrm{H}_{3}$ : Likuiditas berpengaruh positif signifikan terhadap Profitabilitas.

\section{METODE PENELITIAN}

Desain penelitian ini menggunakan pendekatan kuantitatif yang berbentuk asosiatif, yang bertujuan untuk mengetahui pengaruh dua variabel atau lebih 
(variabel bebas) terhadap variabel lainnya (variabel terikat). Penelitian ini bertujuan untuk mengetahui pengaruh struktur modal, kebijakan dividen dan likuiditas perusahaan terhadap profitabilitas perusahaan. Lokasi penelitian pada penelitian ini adalah perusahaan-perusahaan perbankan di Bursa Efek Indonesia tahun 2015-2017. Obyek penelitian dalam penelitian ini yaitu profitabilitas, struktur modal, kebijakan dividen dan likuiditas pada perusahaan perbankan di Bursa Efek Indonesia periode 2015-2017.

Variabel yang digunakan dalam penelitian ini terdapat dua jenis variabel antara lain variabel terikat dan variabel bebas. Variabel terikat dalam penelitian ini adalah profitabilitas (Y) yang diproksikan dengan Return On Assets (ROA). Variabel bebas dalam penelitian ini adalah struktur modal $\left(\mathrm{X}_{1}\right)$ yang diproksikan dengan Debt to Equity Ratio (DER), kebijakan dividen $\left(\mathrm{X}_{2}\right)$ yang diproksikan dengan Dividend Payout Ratio (DPR), dan Likuiditas $\left(\mathrm{X}_{3}\right)$ yang diproksikan dengan Loan to Deposit Ratio (LDR).

ROA dinyatakan dalam bentuk persentase dengan persamaan sebagai berikut:

$$
R O A=\frac{\text { Laba setelah Pajak }}{\text { Assets }} \times 100 \%
$$

DER dinyatakan dalam bentuk persentase dengan persamaan sebagai berikut:

$$
D E R=\frac{\text { Jumlah Utang }}{\text { Ekuitas }} \times 100 \%
$$

DPR dinyatakan dalam bentuk persentase dengan persamaan sebagai berikut:

$$
D P R=\frac{\text { Dividen }}{E A T} \times 100 \%
$$


LDR dinyatakan dalam bentuk persentase dengan persamaan sebagai berikut:

$$
L D R=\frac{\text { Total Kredit yang Diberikan }}{\text { Total Dana Pihak Ketiga }} \times 100 \%
$$

Populasi penelitian ini ialah perusahaan-perusahaan perbankan yang terdaftar di Bursa Efek Indonesia yang selalu mempublikasikan laporan keuangan lengkap selama periode 2015-2017. Sehingga jumlah populasi dalam penelitian ini adalah 39 perusahaan. Metode penentuan sampel dalam penelitian ini menggunakan nonprobalility sampling yaitu sampel jenuh. Jumlah sampel dalam penelitian ini adalah 39 perusahaan.

Metode ini mengumpulkan data dengan cara melakukan dengan mengamati, mencatat, dan mempelajari laporan keuangan tahunan perusahaan perbankan yang dipublikasikan di Bursa Efek Indonesia (BEI) melalui website Indonesia Stock Exchange (IDX).

Jenis data yang digunakan dalam penelitian ini adalah data kuantitatif. Sumber data yang digunakan adalah data sekunder yang diperoleh dari laporan keuangan perusahaan perbankan yang terdaftar di Bursa Efek Indonesia tahun 2015-2017.

Analisis regresi linear berganda digunakan sebagai teknik analisis data yang digunakan pada penelitian ini. Teknik analisis data ini digunakan untuk mengetahui bagaimana pengaruh dari variabel independen terhadap variabel dependen.

Persamaan regresi linear berganda dalam penelitian ini dirumuskan sebagai berikut (Rimbawan, 2013: 319): 
$\hat{\mathrm{Y}}=a+\mathrm{b}_{1} \mathrm{X}_{1}+\mathrm{b}_{2} \mathrm{X}_{2}+\mathrm{b}_{3} \mathrm{X}_{3}+\mathrm{e}$

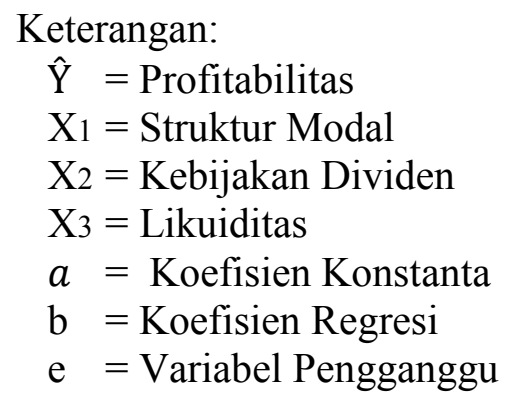

Pengujian asumsi klasik bertujuan untuk memastikan bahwa model yang diperoleh benar-benar memenuhi asumsi dasar dalam analisis regresi. Uji asumsi klasik dilakukan sebelum analisis regresi linear berganda. Uji asumsi klasik yang digunakan untuk menguji kesesuaian model antara lain: uji normalitas, uji multikolinearitas, uji heterokedastisitas, dan uji autokorelasi.

Uji Normailtas digunakan untuk menguji variabel penggangu dan residual dalam model berdistribusi normal atau tidak. Uji normalitas dilakukan dengan menggunakan uji non-parametric Kolmogrof-Smirnov (K-S). Menurut Uji K-S, apabila Uji signifikansi $>0,05$ berarti data residual berdistribusi normal, sedangkan apabila signifikasi $<0,05$ berarti data tidak berdistribusi normal (Ghozali, 2016:157).

Uji Multikolinearitas digunakan untuk mengguji apakah model regresi tersebut diketahui adanya korelasi antar variabel bebas. Model regresi yang baik dapat terjadi apabila tidak ada korelasi antar varibel bebas. Kolerasi antar varibel bebas dapat diketahui dengan melihat nilai tolerance dan variance inflatation factor 
(VIF). Jika nilai tolerance $<1$ dan atau nilai VIF $>10$, maka dapat dikatakan bahwa terjadi multikolinearitas dalam model (Ghozali, 2016:104).

Uji heteroskedastisitas digunakan untuk mengetahui apakah dalam model regresi terdapat ketidaksamaan varians dari residual atau pengamatan ke pengamatan yang lain. Jika variance dari residual satu pengamatan ke pengamatan yang lain tetap, maka disebut homokedastisitas dan jika berbeda disebut heteroskedastisitas. Model regresi yang baik adalah model regresi yang tidak terdapat heteroskedastisitas. Metode yang digunakan mendeteksi gejala heteroskedastisitas adalah metode Glejser. Model dikatakan bebas dari heteroskedastisitas apabila nilai signifikansi lebih besar dari 0,05.

Uji autokorelasi memiliki tujuan untuk mengetahui di dalam model regresi linear terdapat korelasi antara kesalahan pengganggu pada periode-t dengan kesalahan pengganggu pada periode t-l (sebelumnya). Jika terjadi korelasi maka dinamakan ada autokorelasi (Ghozali, 2016:108). Uji autokolerasi dapat dilakukan dengan menggunakan Uji Durbin Watson (DW-Test). DW-Test digunakan untuk mengetahui apakah terdapat autokolerasi atau tidak. Nilai DW-Test tersebut dibandingkan dengan nilai t tabel dengan tingkat keyakinan sebesar 95 persen, bila $\mathrm{du}<\mathrm{dw}<4-\mathrm{du}$, maka tidak terjadi autokolerasi, bila $\mathrm{dw}<\mathrm{dl}$, maka terjadi autokolerasi positif, bila $\mathrm{dw}>4$-dl, berarti terjadi autokolerasi negatif, bila $\mathrm{dl}<\mathrm{dw}$ $<$ du atau 4-du $<$ dw $<4$-dl, maka tidak dapat disimpulkan mengenai ada tidaknya autokolerasi. Pengujian pengaruh serempak menjelaskan apakah semua variabel bebas secara simultan mempunyai pengaruh atau tidak terhadap variabel terikat. Pengujian pengaruh serempak dengan uji $\mathrm{F}$ dapat dilakukan dengan mengikuti 
langkah-langkah sebagai berikut. Formulasi hipotesis $\mathrm{H}_{0}: \beta_{1}=\beta_{2}=\beta_{3}=0$, (artinya tidak ada pengaruh secara simultan antara struktur modal, kebijakan dividen, dan likuiditas terhadap profitabilitas). $H_{1}$ : Paling sedikit salah satu $\beta_{i} \neq 0$, (artinya ada pengaruh secara simultan antara struktur modal, kebijakan dividen, dan likuiditas terhadap profitabilitas). Menentukan tingkat keyakinan $=95$ persen dan taraf nyata $\alpha=5$ persen dan $\mathrm{d} f=(\mathrm{k}-1)(\mathrm{n}-\mathrm{k})$ untuk menentukan $\mathrm{F}_{\text {tabel. Statistik uji akan }}$ dihitung dengan bantuan SPSS 20. Kriteria pengujian dan simpulan sebagai berikut. $\mathrm{H}_{0}$ diterima jika $\mathrm{F}_{\text {hitung }} \leq \mathrm{F}_{\text {tabel }}$ atau tingkat signifikansi $\geq \alpha=5$ persen, $\mathrm{H}_{0}$ ditolak jika $\mathrm{F}_{\text {hitung }}>\mathrm{F}_{\text {tabel }}$ atau tingkat signifikansi $<\alpha=5$ persen.

Pengujian hipotesis menjelaskan seberapa besar pengaruh saru variabel bebas secara individual dalam menerangkan variasi variabel independen. Pengujian ini dilakukan dengan cara membandingkan signifikansi masing-masing variabel bebas dengan $\alpha=10$ persen, $\mathrm{H}_{1}$ diterima jika tingkat signifikansi $\mathrm{t}<\alpha=10$ persen, sedangkan $\mathrm{H}_{1}$ ditolak jika signifikansi $\mathrm{t}>\alpha=10$ persen (Ghozali, 2016:97). Pengujian hipotesis dengan uji t dapat dilakukan dengan mengikuti langkahlangkah sebagai berikut. Hipotesis $1: \mathrm{H}_{0}: \beta_{1}=0$, (artinya secara parsial variabel struktur modal tidak berpengaruh signifikan terhadap Profitabilitas), $\mathrm{H}_{1}: \beta_{1}<0$, (artinya secara parsial variabel struktur modal berpengaruh negatif signifikan terhadap Profitabilitas).

Hipotesis $2: \mathrm{H}_{0}: \beta_{2}=0$, (artinya secara parsial variabel kebijakan dividen tidak berpengaruh signifikan terhadap Profitabilitas), $\mathrm{H}_{2}: \beta_{2}>0$, (artinya secara parsial variabel kebijakan dividen berpengaruh positif signifikan terhadap Profitabilitas). Hipotesis $3: \mathrm{H}_{0}: \beta_{3}=0$, (artinya secara parsial variabel likuiditas 
tidak berpengaruh signifikan terhadap Profitabilitas), $\mathrm{H}_{3}: \beta_{3}>0$, (artinya secara parsial variabel likuiditas berpengaruh positif signifikan terhadap Profitabilitas). Menentukan tingkat keyakinan $=90$ persen dan taraf nyata $\alpha=10$ persen dan $\mathrm{d} f=$ ( $\mathrm{n}$ - k) untuk menentukan $\mathrm{T}_{\text {tabel. }}$ Statistik uji akan dihitung dengan bantuan SPSS 20. Kriteria pengujian dan simpulan sebagai berikut: $\mathrm{H}_{0}$ diterima jika $t_{\text {hitung }} \leq t_{\text {tabel }}$ atau tingkat signifikansi $>\alpha=10$ persen, $\mathrm{H}_{0}$ ditolak jika $\mathrm{t}_{\text {hitung }}>\mathrm{t}_{\text {tabel }}$ atau tingkat signifikansi $\leq \alpha=10$ persen.

\section{HASIL DAN PEMBAHASAN}

Berdasarkan data yang diperoleh dari Bursa Efek Indonesia dapat disajikan laporan deskriptif data populasi berdasarkan variabel-variabel terkait yaitu profitabilitas, struktur modal, kebijakan dividen dan likuiditas selama periode 20152017 sebagai berikut:

Tabel 1.

Statisktik Deskrptif

\begin{tabular}{lrrrrr}
\hline & N & Minimum & Maximum & Mean & Std. Deviation \\
\hline Profitabilitas & 117 & -11.73 & 3.11 & .4020 & 2.36725 \\
Struktur Modal & 117 & 159.37 & 3047.12 & 666.9656 & 348.51155 \\
Kebijakan Dividen & 117 & .00 & 74.83 & 13.1062 & 18.63655 \\
Likuiditas & 117 & 42.02 & 112.54 & 84.5188 & 13.05073 \\
Valid N (listwise) & 117 & & & & \\
\hline Sumber: data diolah, 2018 & & & & &
\end{tabular}

Deskrptif variabel profitabilitas berdasarkan Tabel 1. adalah nilai minimum sebesar $-11,73$ persen, nilai maksimum profitabilitas sebesar 3,11 persen. Data memiliki selisih (range) sebesar 14,84 persen. Nilai rata-rata profitabilitas adalah 0,402 persen selama tahun 2015-2017. Standar deviasi profitabilitas adalah 2,36725. 
Deskrptif variabel struktur modal berdasarkan Tabel 1. adalah nilai minimum sebesar 159,37 persen, sedangkan nilai maksimum struktur modal sebesar 3047,12 persen. Data memiliki selisih (range) sebesar 2887,75 persen. Nilai rata-rata struktur modal adalah 666,9656 persen selama tahun 2015-2017. Standar deviasi struktur modal adalah sebesar 348,51.

Deskrptif variabel kebijakan dividen berdasarkan Tabel 1. adalah nilai minimum sebesar 0,00 persen, nilai maksimum kebijakan dividen sebesar 74,83 persen. Data memiliki selisih (range) sebesar 74,83 persen. Nilai rata-rata kebijakan dividen adalah sebesar 13,11 persen selama tahun 2014-2015. Standar deviasi kebijakan dividen adalah sebesar 18,63655.

Deskrptif variabel profitabilitas berdasarkan Tabel 1. adalah nilai minimum sebesar 42,02 persen, nilai maksimum sebesar 112,54 persen. Data memiliki selisih (range) sebesar 70,52 persen. Nilai rata-rata likuiditas sebesar 84,5188 persen selama tahun 2015-2017. Standar deviasi likuiditas adalah sebesar 13,05073.

Berdasarkan Tabel 2. hasil pengujian normalitas Unstandardized Residual tidak berdistribusi normal, yang ditunjukan dengan nilai signifikansi Kolmogorov Smirnov sebesar $0,000<0,05$. Data yang digunakan dalam analisi regresi linear berganda harus berdistribusi normal sehingga perlu dilakukan pengeluaran data outlier.

Setelah data outlier dihilangkan maka data yang semula 117 data menjadi 96 data (7 perusahaan outlier selama 3 tahun pengamatan). Pengujian normalitas 
dilakukan kembali dan mendapatkan hasil pengujian normalitas yang kedua adalah sebagai berikut:

Berdasarkan hasil pengujian kedua tersebut menunjukkan bahwa data telah terdistribusi dengan normal. Hal ini ditunjukkan dengan tingkat signifikansi sebesar 0,400 yaitu lebih besar dari 0,05 pada uji Kolmogorov - Smirnov.

Tabel 2.

Hasil Uji Normalitas

One-Sample Kolmogorov-Smirnov Test

\begin{tabular}{llr}
\hline & & Unstandardized Residual \\
\hline $\mathrm{N}$ & & 117 \\
Normal Parameters ${ }^{\mathrm{a}, \mathrm{b}}$ & Mean & $0 \mathrm{E}-7$ \\
& Std. Deviation & 1.97544655 \\
& Absolute & .209 \\
Most Extreme & Positive & .144 \\
Differences & Negative & -.209 \\
& & 2.260 \\
Kolmogorov-Smirnov Z & & .000 \\
Asymp. Sig. (2-tailed) & & \\
\hline
\end{tabular}

a. Test distribution is Normal.

b. Calculated from data.

Sumber: data diolah, 2018

Berdasarkan Tabel 4. dijelaskan bahwa masing-masing nilai tolerance dari struktur modal, kebijakan dividen, dan likuiditas adalah 0,940, 0,979, dan 0,927. Hal ini berarti tidak ada kolerasi antarvariabel bebas yaitu nilai tolerance diatas 0,10. Hasil perhitungan VIF dari struktur modal, kebijakan dividen dan likuiditas adalah 1,064, 1,022 dan 1,079.

Nilai VIF variabel-variabel dalam penelitian ini lebih kecil dari 10 yang berarti tidak ada kolerasi antar variabel bebas, sehingga model layak digunakan atau tidak terjadi multikolinearitas. 
Tabel 3.

Hasil Uji Normalitas

\begin{tabular}{lrr}
\hline \multicolumn{3}{c}{ One-Sample Kolmogorov-Smirnov Test } \\
\hline $\mathrm{N}$ & & Unstandardized Residual \\
Normal & Mean & 96 \\
Parameters ${ }^{\text {a,b }}$ & Std. Deviation & $0 \mathrm{E}-7$ \\
& Absolute & .59622479 \\
Most Extreme & Positive & .091 \\
Differences & Negative & .091 \\
& -.061 \\
Kolmogorov-Smirnov Z & .895 \\
Asymp. Sig. (2-tailed) & .400 \\
\hline a. Test distribution is Normal. & \\
b. Calculated from data. & \\
Sumber: data diolah, 2018 &
\end{tabular}

Tabel 4.

Hasil Uji Multikolinearitas

\begin{tabular}{|c|c|c|c|}
\hline \multirow{2}{*}{\multicolumn{2}{|c|}{ Model }} & \multicolumn{2}{|c|}{ Collinearity Statistics } \\
\hline & & Tolerance & VIF \\
\hline \multirow{4}{*}{1} & (Constant) & & \\
\hline & Struktur Modal & .940 & 1.064 \\
\hline & Kebijakan Dividen & .979 & 1.022 \\
\hline & Likuiditas & .927 & 1.079 \\
\hline & ependent Variable: $\mathrm{P}$ & fitabilitas & \\
\hline
\end{tabular}

Berdasarkan Tabel 5. terlihat bahwa signifikansi struktur modal sebesar 0,446 kebijakan dividen sebesar 0,57 , dan likuiditas sebesar 0,912 menunjukan nilai signifikansi lebih besar dari 0,05 yang artinya tidak ada pengaruh variabel bebas yaitu struktur modal, kebijakan dividen dan likuiditas terhadap absolut residual atau variabel bebas tidak mengandung gejala heteroskedastisitas, sehingga layak digunakan untuk memprediksi karena tidak mengandung gejala heteroskedastisitas. 
Tabel 5.

Hasil Uji Heteroskedastisitas (Uji Gletser)

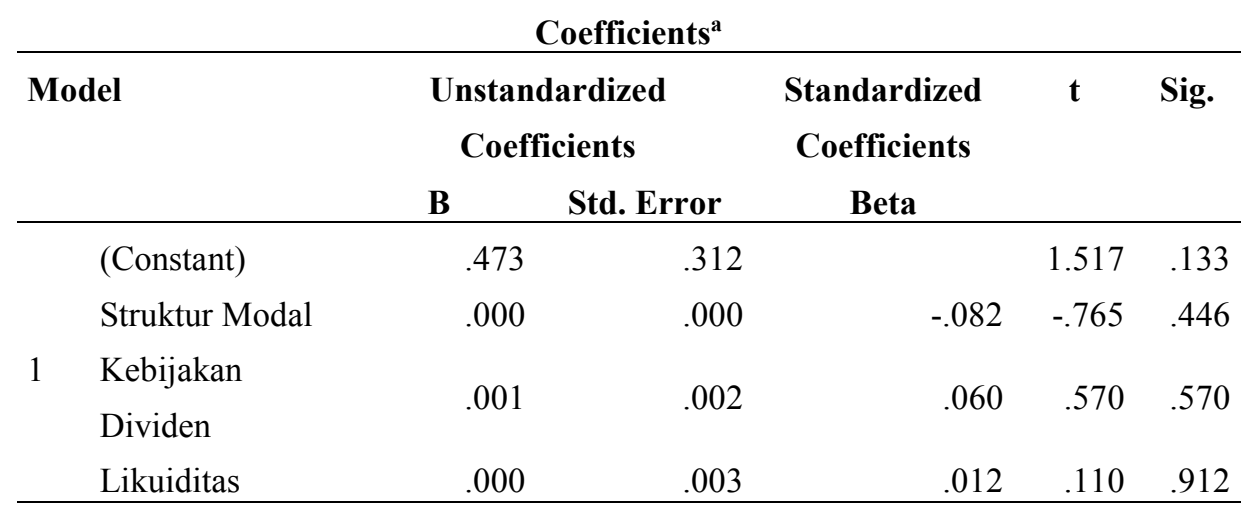

a. Dependent Variable: abs_res

Sumber: data diolah, 2018

Tabel 6.

Hasil Uji Autokolerasi (Durbin Watson)

Model Summary ${ }^{b}$

\begin{tabular}{lrrrrr}
\hline Model & R & R Square & $\begin{array}{l}\text { Adjusted } \\
\text { R Square }\end{array}$ & $\begin{array}{l}\text { Std. Error of } \\
\text { the Estimate }\end{array}$ & $\begin{array}{l}\text { Durbin- } \\
\text { Watson }\end{array}$ \\
\hline 1 & $.633^{\mathrm{a}}$ & .401 & .381 & .60587 & 2.150 \\
\hline
\end{tabular}

a. Predictors: (Constant), Likuiditas, Kebijakan Dividen, Struktur Modal

b. Dependent Variable: Profitabilitas

Sumber: data diolah, 2018

Berdasarkan Tabel 6. diperoleh nilai DW sebesar 2,150 dengan tingkat signifikansi 5 persen, untuk $n=96$ dengan jumlah variabel bebas $(\mathrm{k})$ sebanyak $3, \mathrm{dL}$ $=1,6039$, dan $\mathrm{dU}=1,7326$, dengan demikian model berada pada daerah tidak ada auto kolelasi atau di area $\mathrm{dU}<\mathrm{DW}<4$-dU.

Berdasarkan Tabel 7. yaitu hasil uji regresi diperoleh persamaan regresi sebagai berikut:

$\hat{Y}=0,600-0,001 X_{1}+0,021 X_{2}+0,009 X_{3}$

Keterangan :

$\hat{\mathrm{Y}} \quad=$ Profitabilitas

$\mathrm{X}_{1} \quad=$ Struktur Modal 
$\mathrm{X}_{2} \quad=$ Kebijakan Dividen

$\mathrm{X}_{3} \quad=$ Likuiditas

Nilai konstanta sebesar 0,600 artinya jika variabel struktur modal, kebijakan dividen dan likuiditas dianggap konstan (tetap atau tidak ada perubahan), maka profitabilitas akan bernilai 0,600 persen.

Tabel 7.

Hasil Uji Regresi

\begin{tabular}{|c|c|c|c|c|c|c|}
\hline \multirow{2}{*}{\multicolumn{2}{|c|}{ Model }} & \multicolumn{2}{|c|}{$\begin{array}{l}\text { Unstandardized } \\
\text { Coefficients }\end{array}$} & \multirow{2}{*}{$\begin{array}{c}\text { Standardized } \\
\text { Coefficients } \\
\text { Beta } \\
\end{array}$} & \multirow[t]{2}{*}{$\mathbf{T}$} & \multirow[t]{2}{*}{ Sig. } \\
\hline & & B & Std. Error & & & \\
\hline \multirow{4}{*}{1} & (Constant) & .600 & 466 & & 1.288 & 201 \\
\hline & Struktur Modal & -.001 & .000 & -.255 & -3.064 & .003 \\
\hline & Kebijakan Dividen & .021 & .003 & .536 & 6.565 & .000 \\
\hline & Likuiditas & .009 & .005 & .151 & 1.799 & .075 \\
\hline
\end{tabular}

Koefisien struktur modal bernilai negatif sehingga bertolak belakang dengan profitabilitas. Nilai koefisien struktur modal sebesar $-0,001$ artinya jika nilai struktur modal meningkat sebesar satu persen maka profitabilitas turun sebesar 0,001 persen dengan asumsi variabel kebijakan dividen dan likuiditas tetap konstan.

Koefisien kebijakan dividen bernilai positif sehingga searah terhadap profitabilitas. Nilai koefisien kebijakan dividen sebesar 0,021 artinya jika nilai kebijakan dividen meningkat sebesar satu persen maka profitabilitas naik sebesar 0,021 persen dengan asumsi variabel struktur modal dan likuiditas tetap konstan.

Koefisien likuiditas bernilai positif sehingga searah terhadap profitabilitas. Nilai koefisien likuiditas sebesar 0,009 artinya jika nilai struktur modal meningkat sebesar satu persen maka profitabilitas naik sebesar 0,009 persen dengan asumsi variabel struktur modal dan kebijakan dividen tetap konstan. 
Tabel 8.

Hasil Uji Simultan (Uji F)

\begin{tabular}{|c|c|c|c|c|c|c|}
\hline \multicolumn{2}{|c|}{ Model } & \multirow{2}{*}{$\begin{array}{r}\text { Sum of Squares } \\
22.584\end{array}$} & \multirow{2}{*}{$\frac{\text { Df }}{3}$} & \multirow{2}{*}{$\begin{array}{r}\text { Mean Square } \\
7.528\end{array}$} & \multirow{2}{*}{$\frac{\text { F }}{20.508}$} & \multirow{2}{*}{$\begin{array}{l}\text { Sig. } \\
.000^{\mathrm{b}}\end{array}$} \\
\hline & Regression & & & & & \\
\hline 1 & Residual & 33.771 & 92 & .367 & & \\
\hline & Total & 56.355 & 95 & & & \\
\hline
\end{tabular}

Berdasarkan Tabel 8. diketahui nilai $\mathrm{F}$ hitung adalah 20,508 $>\mathrm{F}$ tabel dan nilai signifikansi $0,000<0,05$ maka hipotesis diterima. Hal ini berarti ketiga variabel bebas yaitu struktur modal, kebijakan dividen, dan likuiditas secara simultan berpengaruh signifikan terhadap variabel terikat yaitu profitabilitas.

Berdasarkan Tabel 7. variabel struktur modal menunjukkan bahwa nilai sig. sebesar 0,003 lebih kecil dari 0,05, maka yang berarti variabel struktur modal berpengaruh signifikan terhadap profitabilitas pada tingkat $\alpha=5$ persen. Nilai $t$ hitung sebesar -3,064 dengan tanda negatif, yang berarti variabel struktur modal mempunyai hubungan yang berbanding terbalik dengan variabel profitabilitas. Simpulannya adalah variabel struktur modal berpengaruh negatif signifikan terhadap profitabilitas atau hipotesis 1 diterima. Hal ini mendukung hasil penelitian ini yang dilakukan oleh Rifai (2014), Afriyanti (2011) serta penelitian Chechet dan Olayiwola (2014).

Variabel kebijakan dividen menunjukkan bahwa nilai sig. sebesar 0,000 lebih kecil dari 0,05, maka yang berarti variabel kebijakan dividen berpengaruh signifikan terhadap profitabilitas pada tingkat $\alpha=5$ persen. Nilai t hitung sebesar 6,565 dengan tanda positif, yang berarti variabel kebijakan dividen mempunyai hubungan yang berberbanding lurus dengan profitabilitas. Simpulannya adalah 
variabel kebijakan dividen berpengaruh positif signifikan terhadap profitabilitas atau hipotesis 2 diterima. Hal ini mendukung hasil penelitian ini yang dilakukan oleh Ajanthan (2013), Fauzi dan Suhadak (2015) serta M'rabet dan Boujjat (2016).

Variabel likuiditas menunjukkan bahwa nilai sig. sebesar 0,075 lebih kecil dari 0,10 , maka yang berarti variabel likuiditas berpengaruh signifikan terhadap profitabilitas. Nilai t hitung sebesar 1,799 dengan tanda positif, yang berarti variabel likuiditas mempunyai hubungan yang berberbanding lurus dengan profitabilitas. Simpulannya adalah variabel likuiditas berpengaruh positif signifikan terhadap profitabilitas pada tingkat $\alpha=10$ persen atau hipotesis 3 diterima. Penelitian ini didukung oleh penelitian terdahulu yang dilakukan oleh Agustiningrum (2013), Fahrul and Rusliati (2016) serta Fahrizal (2014).

\section{SIMPULAN DAN SARAN}

Berdasarkan hasil analisis data dan pembahasan maka dapat diperoleh kesimpulan bahwa struktur modal berpengaruh negatif signifikan terhadap profitabilitas perusahaan, kebijakan dividen berpengaruh positif signifikan terhadap profitabilitas perusahaan dan likuiditas berpengaruh positif signifikan terhadap profitabilitas perusahaan perbankan di Bursa Efek Indonesia periode 2015-2017.

Peneliti selanjutnya yang melakukan penelitian serupa dapat menambah variabel bebas yang bersifat makro yang memiliki pengaruh terhadap profitabilitas. Peneliti lain diharapkan mengembangkan penelitian ini dengan memperluas ruang lingkup dan jenis perusahaan sehingga dapat menjadi sumber informasi bagi peneliti lainnya serta memperpanjang periode pengamatan dalam penelitian. 
Bagi perusahan sektor perbankan hendaknya memperhatikan keputusankeputusan perusahaan terkait dengan struktur modal, kebijakan dividen dan likuiditas. Hal ini berdasarkan hasil penelitian, bahwa variabel struktur modal kebijakan dividen dan likuiditas berpengaruh signifikan terhadap profitabilitas perbankan.

\section{REFERENSI}

Abiola, James O. (2014). Measuring and Analyzing The Effects of Dividend Policy in Banking Profits and Growth. Journal of Policy and Development Studies, 9 (1), 167-178.

Afriyanti, M. (2011). Analisis pengaruh Current Ratio, Total Asset Turnover, Debt to Equity Ratio, Sales dan Size Terhadap ROA. Skripsi Univeritas Diponegoro Semarang.

Agustiningrum, Riski. (2013). Analisis Pengaruh CAR, NPL, dan LDR Terhadap Profitabilitas Pada Perusahaan Perbankan. E-Jurnal Program Studi Manajemen Fakultas Ekonomi dan Bisnis Universitas Udayana, 2 (8), 885-902.

Ajanthan, A. (2013). The Relationship between Dividend Payout and Firm Profitability: A Study of Listed Hotels and Restaurant Companies in Sri Lanka. International Journal of Scientific and Reaserch Publications, 3 (6), 1-6

Akhtar, M.F., Ali, K. \& Sadaqat, S., (2011). Factors Influencing the Profitability of Islamic Banks of Pakistan. International Research Journal of Finance and Economics, 66, 125-132.

Audhya, Rahayu Kartika Dewi Putu. (2014). Pengaruh Perputaran Kas, LDR, dan CAR Terhadap Profitabilitas Pada LPD Desa Bondalem. E-Jurnal Program Studi Manajemen Fakultas Ekonomi dan Bisnis Universitas Udayana, 3 (1), 169-182.

Binangkit, A. Bagas \& Sugeng Raharjo. (2014). Pengaruh Struktur Modal terhadap Kinerja Perusahaan dan Harga Saham pada Perusahaan Manufaktur di Bursa Efek Indonesia. Aktual Edisi Pebruari, 1 (2), 24-26.

Brigham, E. F. \& Houston, Joel F. (2011). Dasar-dasar Manajemen Keuangan Terjemahan. Edisi 10. Jakarta: Salemba Empat.

Chechet, I., L. \& Olayiwola, A., B. (2014). Capital Structure and Profitability of Nigerian Quoted Firms: The Agency Cost Theory Perspective. American International journal of Social Science, 3 (1), 139-158. 
Chen, Jianguo \& Nont Dhiensiri. (2009). Determinants of Dividend Policy: The Evidence from New Zealand. International Research Journal of Finance and Economics, 34.

Damayanti, P., \& Minarsavitri, D. A. (2012). Analisis Pengaruh Ukuran (Size), Capital Adequacy Ratio (CAR), Pertumbuhan Deposit, Loan To Deposit Ratio (LDR), Terhadap Profitabilitas Perbankan Go Public di Indonesia Tahun 20052009 (Studi Empiris Perusahaan Perbankan yang Terdaftar di BEI). Jurnal Ilmiah Manajemen Dan Akuntansi Terapan (JIMAT), 3 (2), 45-54.

Fahrizal \& Henny Rahyuda. (2014). Pengaruh Risiko Usaha terhadap Profitabilitas pada Lembaga Perkreditan Desa di Kecamatan Kuta Kabupaten Badung Periode 2010-2012. E- Jurnal Manajemen Universitas Udayana, 3 (10). 3067 3077

Fahrul, M., Syafi, R., \& Rusliati, E. (2016). Credit Risk, Market Risk, Operational Risk and Liquidity Risk on Profitability of Banks in Indonesia. Trikonomika, 15 (2), 78-88.

Farsio, F., Geary, A., \& Moser, J. (2004). The Relationship Between Dividends and Earnings. Journal for Economic Educators, 4 (4), 1-5.

Fauzi, Mohammad Nur \& Suhadak. (2015). Pengaruh Kebijakan Dividen Dan Pertumbuhan Perusahaan Terhadap Struktur Modal Dan Profitabilitas. Jurnal Administrasi Bisnis (JAB), 24 (1), 1-10.

Ghozali, Imam. (2016). Aplikasi Analisis Multivariate Dengan Program IMB SPSS 23. Edisi 10. Semarang: Badan Penerbit Universitas Diponogoro.

Habbe, H. A., Ali, M. \& Sabir, M. (2012), Influence of Bank Health Ratios on Financial Performance of Sharia Commercial Banks and Conventional Banks in Indonesia, Journal of Analysis, 1 (1).

Javaid, Saira, Jamil Anwar, Khalid Zaman, \& Abdul Gafoor. (2012). Determinants of Bank Profitability in Pakistan: Internal Factor Analysis. Mediterranean Journal of Social Sciences, 2 (1), 59-78.

Kasmir. (2011). Manajemen Perbankan. Edisi Revisi. Jakarta: Rajawali Pers.

M'rabet, Rachid and Wiame Boujjat. (2016). The Relationship Between Dividend Payments And Firm Performance: A Study Of Listed Companies In Morocco. European Scientific Journal, 12 (4), 469-482.

Marusya dan Magantar. (2016). Pengaruh Struktur Modal Terhadap Profitabilitas Pada Perusahaan Tobacco Manufacturers Yang Terdaftar Di Bursa Efek 
Indonesia (BEI) Periode 2008-2015. Jurnal Berkala Ilmiah Efisiensi, 16 (3), 484-492.

Miadalyni, Putu Desi. (2013). Pengaruh Loan to Deposit Ratio, Loan to Asset Ratio, Capital Adequacy Ratio dan Kualitas Aktiva Produktif Terhadap Profitabilitas Pada PT Bank Pembangunan Daerah Bali Kantor Pusat Denpasar. E-Jurnal Manajemen Universitas Udayana, 2 (12), 1542-1558.

Paleni, H. Subuh Hidayat and Dadang Prasetyo Jatmiko. (2017). Determinants of Profitability : Evidence from Indonesian Firms. International Journal of Economic Perspectives, 11 (3), 1049-1057.

Purwoko, D., \& Sudiyatno, B. (2013). Faktor-Faktor yang Mempengaruhi Kinerja Bank (Studi Empirik pada Industri Perbankan di Bursa Efek Indonesia). Journal of Business Economics and Management, 20 (1), 25-39.

Radjamin, Iryuvita Januarizka Putri dan I Made Sudana. (2014). Penerapan Pecking Order Theory dan Kaitannya dengan Pemilihan Struktur Modal Perusahaan pada Sektor Manufaktur di Negara Indonesia dan Negara Australia. Jurnal Manajemen Bisnis Indonesia, 1 (3), 415-468.

Rifai, Moh. (2014). Pengaruh Ukuran Perusahaan, Struktur Modal dan Pertumbuhan Perusahaan Terhadap Profitabilitas Studi Pada Perusahaan Manufaktur di BEI Tahun 2010-2012. Jurnal Akuntansi. Universitas Pandanaran Semarang, 1 (1)

Rimbawan, Nyoman Dayuh. (2013). Statistik Inferensial untuk Ekonomi dan Bisnis. Denpasar: Udayana University Press.

Rismawati, Ni Made dan I Made Dana. (2014). Pengaruh Pertumbuhan Aset dan Tingkat Suku Bunga Sertifikat Bank Indonesia (SBI) Terhadap Kebijakan Dividen Dan Nilai Perusahaan Pada Perusahaan Manufaktur Di Bursa Efek Indonesia(BEI). E-Jurnal Manajemen Universitas Udayana, 3 (4), 988-1004.

Ronoh, C., Jomo Kenyatta And J., Jomo Kenyatta Ntoiti. (2015). Effect Of Capital Structure On Financial Performance Of Listed Commercial Banks In Kenya. A Case Study Of Kenya Commercial Bank Limited. Strategic Journal of Business \& Change Management, 2 (2), 750-781.

Saleem, Qasim and Ramiz Ur Rehman. (2011). Impacts of Liquidity Ratios on Profitability. Interdisciplinary Journal of Research in Business, 1 (7), 95 -98.

Sartono, Agus. 2012. Manajemen Keuangan Teori dan Aplikasi Edisi Keempat. Yogyakarta: BPFE.

Shaputri, Silvia Juni dan Seto Sulaksono Adi Wibowo. (2016). Pengaruh Struktur Modal terhadap Kinerja Perusahaan Non Keuangan yang terdaftar di BEI. Jurnal Akuntansi, Ekonomi dan Manajemen Bisnis, 4 (2), 107-114. 
Sudirman, I Wayan. (2013). Manajemen Perbankan Menuju Bankir Kovensional yang Profesional. Edisi Pertama. Jakarta: Kencana Prenada Media Group.

Sukmawati, N.M. Elin dan I. B. Anom Purbawangsa. (2016). Pengaruh Pertumbuhan Dana Pihak Ketiga, Pertumbuhan Kredit, Risiko Kredit, Likuiditas, dan Kondisi Ekonomi Terhadap Profitabilitas. E-Jurnal Manajemen Unud, 5 (9), 5398-5432.

Thafani, Fathima AR and M.A. Mohamed Abdullah. (2014). Impact of Dividend Payout on Corporate Profitability: Evident from Colombo Stock Exchange. Advances in Economics and Business Management, 1 (1), 27-33

Veithzal Rivai, Andria Permata Veithzal, Ferry N. Idroes. (2007). Bank and Financial Institution Management. Jakarta: PT. Rajagrafindo Persada.

Velnampy, T and Niresh Aloy, J. (2012). The Relationship Between Capital Structure and Profitability. Global Journal Of Management And Business Research Inc, 12 (13), 589-62.

Warsa, N.M.I Uthami Putrid an I.K. Mustanda. (2016). Pengaruh CAR, LDR dan NPL Terhadap ROA pada Sektor Perbankan di Bursa Efek Indonesia. E-Jurnal Manajemen Unud, 5 (5), 2842 - 2870.

Wiagustini, Ni Luh Putu. (2013). Dasar-dasar Manjemen Keuangan. Denpasar: Udayana University Press.

Zaineldeen, Mohammed. (2018). Liquidity and Profitability Analysis in The Palestinian Banking Sector. Journal of International Trade, Logistics and Law, 4 (1), 44-53. 